\title{
Al Toxicity of Wheat Grown in Acidic Subsoils in Relation to Soil Solution Properties and Exchangeable Cations
}

\author{
S. J. Carr and G. S. P. Ritchie
}

\begin{abstract}
Toxic concentrations of soluble $\mathrm{Al}$ in the subsoil decrease the yield of wheat grown on many yellow earths in the eastern wheatbelt of Western Australia. In our previous research (Carr et al. 1991), we observed variable plant response to high concentrations of soluble Al in subsoils of yellow earths in different regions of the wheatbelt. Environmental conditions (e.g. water supply) and/or an unidentified soil mitigating factor may have contributed to the variable plant response to soluble $\mathrm{Al}$ in some of the regions studied.

We collected ten soils from four regions of the eastern wheatbelt of Western Australia. In a glasshouse experiment using these soils, we studied the effect of soil solution and $\mathrm{KCl}$ extract properties on wheat growth under uniform environmental conditions. The concentration of $\mathrm{Al}$ in a $0.005 \mathrm{M} \mathrm{KCl}$ extract was able to explain $97 \%$ of the variation in root fresh weight of wheat grown in the 10 soils, even though the soil solution properties were found to differ markedly between regions. For example, $97 \%$ of the variation in root fresh weight (RFW) was explained by the total [Al] in soil solution extracted from soils in one region (Merredin). In comparison, $58 \%$ of the variation in RFW was explained by the total [Al] in the soil solution extracted from soils collected from all four regions studied.

Ionic strength differences and possibly $\left[\mathrm{SO}_{4}\right]$ were the major chemical properties that differed between Merredin and the other regions studied. These chemical differences presumably altered the toxic proportion of $\mathrm{Al}$ in the soil solution, and hence, the plant response in some regions. The effect of ionic strength on toxic $\mathrm{Al}$ appeared to be simulated by extraction of the soil with $0.005 \mathrm{M} \mathrm{KCl}$.
\end{abstract}

\section{Introduction}

Despite the fact that many highly weathered soils have deep soil profiles, the chemical nature of the subsoil can often restrict root proliferation (Adams and Moore 1983; Radcliffe et al. 1986). In general, the inability of acid sensitive species to penetrate subsoil horizons containing high concentrations of soluble aluminium and low amounts of available calcium results in a decrease in yield. The primary effect of aluminium toxicity is retarded root growth (Foy 1974). However, restricted root penetration is not readily detectable from shoot growth, particularly when the surface soil remains moist, and may only become apparent during periods of drought or other stresses (Pinkerton and Simpson 1981). In the Mediterranean climate of the Western Australian wheatbelt, drought stress is frequently observed during the spring when the wheat crops rely heavily on 
subsoil water, hence the ability to yield well is highly dependent upon adequate subsoil root proliferation.

The yellow sandplain soils in the eastern wheatbelt of Western Australia have naturally acidic subsoils which can restrict the growth and yield of wheat (Porter and Wilson 1984). Aluminium toxicity has been identified as the cause of yield loss on this soil type (Carr et al. 1991). Carr et al. (1991) correlated the yield of wheat with various indices calculated from the concentration of aluminium and other cations ( $\mathrm{Ca}, \mathrm{Mg}$ and $\mathrm{Na}$ ) and with $\mathrm{pH}$ in both soil solution and 1:5 $0.005 \mathrm{M} \mathrm{KCl}$ extracts. Total [Al] was found to be well correlated to the grain yield of wheat grown on yellow earths of the Merredin region in the Western Australian wheatbelt. On the other hand, the ratios $[\mathrm{Al}] /[\mathrm{Na}]$ and $[\mathrm{Al}] /[\mathrm{Ca}]$ were better at explaining the variation in grain yield of wheat grown on yellow earths from several different regions. Measures of $\mathrm{pH}$ were unable to predict grain yield within or between a region. It was suggested that soil chemical differences (e.g. type and concentration of soluble anions that detoxify $\mathrm{Al}$ ) or environmental conditions may have been responsible for the inability of total [Al] to explain adequately the variation in grain yield when soils from different regions were considered together.

The objective of our research was to establish, under uniform environmental conditions, whether differences in soil properties could be used to explain variable plant responses to aluminium toxicity. To achieve this, we conducted detailed chemical analyses on soil solution and $\mathrm{KCl}$ extracts to determine if there were differences in soil chemical characteristics in yellow earth soils collected from different regions of the wheatbelt. In the glasshouse, we investigated whether (i) the short-term shoot and root growths of wheat (i.e. a bioassay) grown in limed and unlimed soils were uniformly correlated to acid soil indices; and (ii) if the bioassay technique for aluminium toxicity can be used to predict grain yield of wheat in the field grown on yellow earths with different concentrations of $\mathrm{Al}$ in the subsoil.

\section{Materials and Methods}

We studied wheat grown on ten soils in the presence of two rates of lime in a glasshouse experiment. Soils were collected from five sites in the Merredin region in order to define a yield response to aluminium toxicity because previous research had indicated that the chemical properties of these soils (other than Al) were similar (Carr et al. 1991). Soils from other regions known to contain toxic concentrations of $\mathrm{Al}$ were sampled to determine if plant growth on these soils responded similarly to plants grown on the Merredin soils under uniform environnmental conditions. In a preliminary experiment to assess wheat growth in the 10 acidic subsoils (that all contained between 2 and $3 \mathrm{ppm}$ bicarbonate extractable $\mathrm{P}$ ), we demonstrated that plant growth was not limited by $\mathrm{P}$ deficiency during the first 10 days growth.

\section{Soils}

All soils were lateritic podzolic yellow sandplain soils from the Norpa series (Bettenay and Hingston 1961). At each site, subsoil was collected from the $15-25 \mathrm{~cm}$ layer because the concentration of aluminium extracted by $0.005 \mathrm{M} \mathrm{KCl}$ from this depth was highly correlated to the grain yield of wheat grown on the soils (Carr et al. 1991). Five sites were in the Merredin region $\left(31^{\circ} \mathrm{S} ., 118^{\circ} \mathrm{E}\right.$.), two near Sullivan $\left(28^{\circ} \mathrm{S}\right.$, $\left.115^{\circ} \mathrm{E}.\right)$, two near Latham $\left(29^{\circ} \mathrm{S} ., 116^{\circ} \mathrm{E}\right.$. and one from Dalwallinu $\left(30^{\circ} \mathrm{S}\right.$., $116^{\circ} \mathrm{E}$.). The sites were chosen as previous observation showed they would provide a range of aluminium concentrations (both in soil solution and 1:5 $0.005 \mathrm{M} \mathrm{KCl}$ extracts). All soils were air dried and sieved through a $4 \mathrm{~mm}$ sieve. 


\section{Experimental Design}

Lime was applied to half of the soils at $2 \cdot 1 \mathrm{~g}$ per $3 \mathrm{~kg}$ soil (equivalent to approximately $2 \mathrm{t} / \mathrm{ha}$ ). After liming and prior to planting wheat, all soils were incubated at $20 \pm 1^{\circ} \mathrm{C}$ for one week at field capacity. There was no nutrient addition in the experiment because we considered seed reserves would be adequate for the short growing period (10 days) and we wanted to minimize changes in the ionic strength of the soils used in this study. Fifteen uniform, germinated wheat seedlings (Triticum aestivum cv. Aroona) with a radicle length of $0.5 \mathrm{~mm}$ were planted at a depth of $1 \mathrm{~cm}$ into soil in plastic-lined, $3 \mathrm{~kg}$ pots and maintained at $20 \pm 1^{\circ} \mathrm{C}$ in root-cooling tanks. The variety Aroona was selected for use as a bioassay plant because of its low tolerance to aluminium. The pots were watered to field capacity daily ( $10 \%$ $\mathrm{w} / \mathrm{v})$. Six days after seeding, the plants were thinned to 12 per pot.

\section{Yield Assessment}

After 10 days, all plants were harvested by cutting the shoots off at the soil surface and the shoots were weighed immediately. Root fresh weight was determined after washing to separate the roots from the soil and after drying with absorbent tissue paper. Root length was estimated using a Comair root length scanner (Commonwealth Aircraft Corporation Ltd., Melbourne) and the length of root produced per gram fresh weight (root fineness) was calculated. The shoots were dried at $70 \pm 1^{\circ} \mathrm{C}$ for $48 \mathrm{~h}$ before measuring dry weights. Relative yields for each of the yield parameters were estimated (by expressing yield in unlimed soils as a percentage of the yields obtained in the limed soils).

Table 1a. Cation concentrations $(\mu \mathrm{M})$ in the soil solution of unlimed soils

\begin{tabular}{rcrrrrrrr}
\hline Soil & Region & \multicolumn{1}{c}{$\mathrm{Al}$} & $\mathrm{Ca}$ & $\mathrm{Mg}$ & $\mathrm{Na}$ & $\mathrm{K}$ & $\mathrm{pH}$ & $\mathrm{EC}^{\mathrm{A}}$ \\
\hline 1 & Merredin & 13 & 491 & 224 & 1056 & 284 & $4 \cdot 08$ & $0 \cdot 34$ \\
2 & Merredin & 240 & 714 & 383 & 607 & 442 & $3 \cdot 77$ & $0 \cdot 49$ \\
3 & Merredin & 18 & 1078 & 343 & 1492 & 336 & $4 \cdot 09$ & $0 \cdot 63$ \\
4 & Merredin & 12 & 438 & 192 & 633 & 94 & $4 \cdot 19$ & $0 \cdot 25$ \\
5 & Merredin & 36 & 870 & 362 & 854 & 224 & $4 \cdot 10$ & $0 \cdot 42$ \\
6 & Latham & 46 & 952 & 255 & 844 & 188 & $3 \cdot 98$ & $0 \cdot 41$ \\
7 & Latham & 57 & 617 & 154 & 386 & 127 & $3 \cdot 96$ & $0 \cdot 29$ \\
8 & Sullivan & 9 & 987 & 428 & 1599 & 316 & $4 \cdot 27$ & $0 \cdot 62$ \\
9 & Sullivan & 226 & 2603 & 985 & 2399 & 452 & $3 \cdot 79$ & $1 \cdot 43$ \\
10 & Dalwallinu & 32 & 294 & 60 & 512 & 337 & $4 \cdot 12$ & $0 \cdot 18$ \\
\hline
\end{tabular}

A Electrical conductivity $(\mathrm{mS} \mathrm{cm}-1)$.

Table 1b. Anion concentrations $(\mu \mathrm{M})$ in the soil solution of unlimed soils

\begin{tabular}{rcrrrrrr}
\hline Soil & Region & $\mathrm{SO}_{4}$ & $\mathrm{NO}_{3}$ & $\mathrm{Cl}$ & $\begin{array}{c}\Sigma \text { cations } \\
\mu \mathrm{M}(+)\end{array}$ & $\begin{array}{c}\Sigma \text { anions } \\
\mu \mathrm{M}(-)\end{array}$ & $\begin{array}{c}\Sigma \text { cations } \\
- \text { anions } \\
\mu \mathrm{M}( \pm)\end{array}$ \\
\hline 1 & Merredin & 105 & 688 & 1476 & 2810 & 2374 & 437 \\
2 & Merredin & 89 & 2088 & 670 & 3964 & 2936 & 1028 \\
3 & Merredin & 145 & 2397 & 1746 & 4722 & 4432 & 290 \\
4 & Merredin & 259 & 732 & 354 & 2023 & 1605 & 417 \\
5 & Merredin & 160 & 1859 & 2086 & 3651 & 4265 & -614 \\
6 & Latham & 497 & 1083 & 766 & 3582 & 2843 & 740 \\
7 & Latham & 332 & 930 & 523 & 2227 & 2118 & 109 \\
8 & Sullivan & 378 & 807 & 2870 & 4771 & 4433 & 339 \\
9 & Sullivan & 155 & 8011 & 3186 & 10705 & 11507 & -801 \\
10 & Dalwallinu & 194 & 426 & 589 & 1654 & 1403 & 251 \\
\hline
\end{tabular}




\section{Soil Analysis}

Immediately before sowing the experiment, soil solution was extracted by centrifugation (16 $\mathrm{h}$ incubation at $12 \%$ gravimetric water content; Gillman 1976) and $1: 50.005 \mathrm{M} \mathrm{KCl}$ extracts from the unlimed soils were analysed for $\mathrm{pH}, \mathrm{Al}, \mathrm{Ca}, \mathrm{Mg}, \mathrm{Na}, \mathrm{K}$ and $\mathrm{EC}$ as previously described (Carr et al. 1991). The concentrations of anions in the soil solutions ( $\mathrm{SO}_{4}^{2-}, \mathrm{NO}_{3}^{-}$ and $\mathrm{Cl}^{-}$) and in the $\mathrm{KCl}$ extracts $\left(\mathrm{SO}_{4}^{2-}\right.$ and $\mathrm{NO}_{3}^{-}$) were measured by ion chromatography. Previous studies indicated that soil solution $\left[\mathrm{F}^{-}\right]$was undetectable using ion chromatography (C. McLay, pers. comm.). Exchangeable cations ( $\mathrm{Al}, \mathrm{Ca}, \mathrm{Mg}, \mathrm{Na}$ and $\mathrm{K}$ ) in 1:10 soil to solution ratio of $0.1 \mathrm{M} \mathrm{BaCl}_{2}$ were also measured in the unlimed soils, and the effective cation exchange capacity (ECEC) was estimated from the summation of the exchangeable cations. The \% Al saturation was calculated as the proportion of the ECEC.

\section{Speciation of $\mathrm{Al}$}

The speciation of $\mathrm{Al}$ in the unlimed soil solution and $\mathrm{KCl}$ extracts was estimated using a chemical equilibrium program, TITRATOR (Cabaniss 1987). As fluoride was not detected in the soil solutions, we assumed a negligible effect on $\mathrm{Al}$ speciation. Formation constants were taken from Lindsay (1978) and Martell and Smith (1977). The species considered were $\mathrm{Al}^{3+}$, $\mathrm{Al}(\mathrm{OH})^{2+}, \mathrm{Al}\left(\mathrm{OH}_{2}\right)^{+}$and $\mathrm{Al}\left(\mathrm{SO}_{4}\right)^{+}$.

\section{Data Analysis}

All absolute and relative yields were correlated to soil test indices which had been previously correlated with grain yield in field experiments (Carr et al. 1991). The soil test indices varied according to whether they accounted for (i) mitigating factors such as $\mathrm{Ca}$ and/or (ii) ionic strength as estimated by cation summation in the soil solution; EC of the soil solution; or $[\mathrm{Na}]$ or $\left[\mathrm{NO}_{3}\right]$ in the soil solution or a $\mathrm{KCl}$ extract.

\section{Results}

\section{Chemical Properties of the Soils}

\section{Soil solution}

A summary of the total concentration of all ions present in the soil solution is given in Tables $1 a$ and $1 b$. There was a large range in the concentrations of cations in the soil solution. The aluminium concentration, [Al], of the soil solution varied from 9 to $240 \mu \mathrm{M}$ despite the narrow range of soil solution $\mathrm{pH}$ $(3 \cdot 77-4 \cdot 27)$. The soil solution [Ca] varied from 294 to $2603 \mu \mathrm{M}$, with only two of the ten sites having more than $1000 \mu \mathrm{M}$. Apart from the extremes (985 and $60 \mu \mathrm{M}$ for soils 9 and 10 respectively), eight of the ten sites had [Mg] between 150 and $428 \mu \mathrm{M}$. Generally, there was little difference between regions in the concentration of soil solution cations. One soil from the Sullivan region (soil 9) contained cation concentrations far in excess of all other soils.

The range of soil solution concentrations observed for the anions were: $\left[\mathrm{SO}_{4}\right]$ $(89-497 \mu \mathrm{M}),\left[\mathrm{NO}_{3}\right](426-8011 \mu \mathrm{M})$ and $[\mathrm{Cl}](354-3186 \mu \mathrm{M})$. The average $\left[\mathrm{SO}_{4}\right]$ in soils from the Merredin region $(152 \mu \mathrm{M})$ was less on average than the concentration in the other regions $(311 \mu \mathrm{M})$. There were no apparent differences in the $\left[\mathrm{NO}_{3}\right]$ in soils from the Merredin region and the other regions (except the very high concentration in soil 9), however, the [Cl] of the two Sullivan soils were considerably greater than all other soils (Table 1).

In general, soils from the Merredin region showed a slight excess of cations over anions, compared with the soils from the other regions (Table 1), however, the difference was not large. 
Table 2. Percentage variation $\left(r^{2}\right)$ in the concentration of ions in the soil solution explained by the electrical conductivity of the soil solution equation of fitted line: $y=a+b x$

\begin{tabular}{lccccccc}
\hline Region & $\mathrm{Ca}$ & $\mathrm{Mg}$ & $\mathrm{Na}$ & $\mathrm{K}$ & $\mathrm{SO}_{4}$ & $\mathrm{NO}_{3}$ & $\mathrm{Cl}$ \\
\hline All regions & 97 & 96 & 83 & 39 & 3 & 90 & 62 \\
Merredin only & 84 & 63 & 40 & 54 & 28 & 86 & 22 \\
\hline
\end{tabular}

Table 3. Concentration $(\mu \mathrm{M})$ of aluminium species present in soil solution and $\mathrm{KCl}$ extracts of unlimed soils

\begin{tabular}{|c|c|c|c|c|c|c|c|}
\hline$\overline{\text { Soil }}$ & {$\left[\mathrm{Al}_{\mathrm{T}}\right]$} & $\overline{\mathrm{Al}^{3+}}$ & $\overline{\mathrm{AlSO}_{4}^{+}}$ & $\mathrm{Al}(\mathrm{OH})^{2+}$ & $\mathrm{Al}\left(\mathrm{OH}_{2}\right)^{+}$ & $\begin{array}{l}\mathrm{Al}^{3+} \text { as a } \\
\% \text { of }\left[\mathrm{Al}_{\mathrm{T}}\right]\end{array}$ & $\begin{array}{c}\mathrm{AlSO}_{4}^{+} \text {as a } \\
\% \text { of }\left[\mathrm{Al}_{\mathrm{T}}\right]\end{array}$ \\
\hline \multicolumn{8}{|c|}{ Soil solution } \\
\hline 1 & 13 & 11.0 & 0.75 & 0.85 & 0.41 & 85 & 6 \\
\hline 2 & 240 & $221 \cdot 3$ & $9 \cdot 49$ & $7 \cdot 70$ & $1 \cdot 73$ & 92 & 4 \\
\hline 3 & 18 & $15 \cdot 5$ & 1.04 & 1.04 & 0.46 & 86 & 6 \\
\hline 4 & 12 & $8 \cdot 8$ & $1 \cdot 69$ & 0.93 & $0 \cdot 61$ & 73 & 14 \\
\hline 5 & 36 & $29 \cdot 9$ & $2 \cdot 68$ & $2 \cdot 30$ & $1 \cdot 14$ & 83 & 7 \\
\hline 6 & 46 & $33 \cdot 7$ & $9 \cdot 52$ & 1.99 & 0.75 & 73 & 21 \\
\hline 7 & 57 & $43 \cdot 7$ & $9 \cdot 73$ & $2 \cdot 64$ & 1.00 & 77 & 17 \\
\hline 8 & 9 & $6 \cdot 7$ & 1.19 & 0.69 & 0.47 & 74 & 13 \\
\hline 9 & 226 & $211 \cdot 3$ & $7 \cdot 95$ & $5 \cdot 54$ & 1.04 & 93 & 4 \\
\hline 10 & 32 & $24 \cdot 3$ & $3 \cdot 98$ & $2 \cdot 33$ & $1 \cdot 35$ & 76 & 12 \\
\hline \multicolumn{8}{|c|}{$\mathrm{KCl}$} \\
\hline 1 & 9 & $8 \cdot 0$ & 0.17 & 0.58 & 0.27 & 89 & 2 \\
\hline 2 & 74 & $65 \cdot 3$ & $1 \cdot 71$ & $4 \cdot 72$ & $2 \cdot 19$ & 88 & 2 \\
\hline 3 & 8 & $7 \cdot 1$ & 0.13 & 0.51 & 0.24 & 89 & 2 \\
\hline 4 & 4 & $3 \cdot 5$ & 0.11 & 0.25 & 0.12 & 88 & 3 \\
\hline 5 & 22 & $19 \cdot 4$ & 0.54 & $1 \cdot 40$ & 0.65 & 88 & 2 \\
\hline 6 & 30 & $25 \cdot 9$ & 1.32 & 1.87 & 0.87 & 86 & 4 \\
\hline 7 & 52 & $45 \cdot 2$ & $2 \cdot 01$ & $3 \cdot 27$ & $1 \cdot 52$ & 87 & 4 \\
\hline 8 & 4 & $3 \cdot 5$ & 0.15 & 0.25 & 0.12 & 87 & 4 \\
\hline 9 & 32 & $28 \cdot 1$ & 0.97 & $2 \cdot 03$ & 0.94 & 88 & 3 \\
\hline 10 & 48 & $42 \cdot 1$ & $1 \cdot 39$ & 3.05 & 1.41 & 88 & 3 \\
\hline
\end{tabular}

Table 4. Cation and anion concentrations $(\mu \mathrm{M})$ in $1: 50.005 \mathrm{M} \mathrm{KCl}$ extracts of unlimed soils

\begin{tabular}{rrrrrrrr}
\hline Soil & $\mathrm{Al}$ & $\mathrm{Ca}$ & $\mathrm{Mg}$ & $\mathrm{Na}$ & $\mathrm{pH}$ & $\mathrm{SO}_{4}$ & $\mathrm{NO}_{3}$ \\
\hline 1 & 9 & 178 & 74 & 54 & $4 \cdot 52$ & 35 & 5 \\
2 & 74 & 60 & 28 & 12 & $4 \cdot 04$ & 44 & 32 \\
3 & 8 & 229 & 81 & 73 & $4 \cdot 35$ & 31 & 17 \\
4 & 4 & 226 & 107 & 44 & $4 \cdot 28$ & 50 & 8 \\
5 & 22 & 233 & 94 & 37 & $4 \cdot 26$ & 47 & 17 \\
6 & 30 & 194 & 51 & 21 & $4 \cdot 16$ & 95 & 6 \\
7 & 52 & 106 & 23 & 7 & $4 \cdot 16$ & 74 & 8 \\
8 & 4 & 253 & 105 & 104 & $4 \cdot 43$ & 70 & 10 \\
9 & 32 & 185 & 61 & 79 & $4 \cdot 12$ & 58 & 61 \\
10 & 48 & 97 & 24 & 22 & $4 \cdot 14$ & 55 & 7 \\
\hline
\end{tabular}


At 9 of the 10 sites, the EC of the soil solution was between 0.18 and 0.63 $\mathrm{mS} \mathrm{cm}{ }^{-1}$. The exception was soil 9 from Sullivan which had an EC of 1.43 $\mathrm{mS} \mathrm{cm}{ }^{-1}$. The EC was well correlated to $[\mathrm{Ca}],[\mathrm{Mg}],\left[\mathrm{NO}_{3}\right]$ and $[\mathrm{Na}]$ in the soil solution, but not to $[\mathrm{K}],[\mathrm{Cl}]$ and $\left[\mathrm{SO}_{4}\right]$ (Table 2). Soil solution $[\mathrm{Ca}]$ and $\left[\mathrm{NO}_{3}\right]$ in soils from the Merredin region were also well correlated to soil solution EC (Table 2).

The free ion, $\mathrm{Al}^{3+}$, was the major form of $\mathrm{Al}$ in all soils (Table 3). In four of the five Merredin soils, greater than $83 \%$ of the total $\mathrm{Al}$ was present as $\mathrm{Al}^{3+}$, whereas four of the five soils from other regions had less than $77 \%$ of the total $\mathrm{Al}$ present as $\mathrm{Al}^{3+}$. The proportion of the total $\mathrm{Al}$ complexed with sulfate in soils from regions other than Merredin was approximately twice that found in the Merredin soils (13\% compared with $7 \%$, Table 3 ).

\section{$\mathrm{KCl}$ extracts}

The ion concentrations in the $\mathrm{KCl}$ extracts (Table 4) were less than those in the soil solution. For example, [Al] varied from 4 to $74 \mu \mathrm{M}$ and the $\mathrm{pH}$ varied from 4.04 to 4.52 . Unlike the soil solution, the $\mathrm{KCl}$ did not extract substantially higher ion concentrations from soil 9 compared with all other soils. The average $\left[\mathrm{SO}_{4}\right]$ extracted by $\mathrm{KCl}$ from soils of the Merredin region was $42 \mu \mathrm{M}$, whereas the average $\left[\mathrm{SO}_{4}\right]$ of soils from other regions was $70 \mu \mathrm{M}$. Otherwise, there were no distinct differences between soils from the Merredin region and soils from the other regions in the concentrations of ions extracted by the $\mathrm{KCl}$. Despite similar soil solution [Al] for soils 2 and 9 (240 and $226 \mu \mathrm{M}$ respectively), the $\mathrm{KCl}$ extracted a greater amount of Al from soil $2(74 \mu \mathrm{M})$ compared with soil 9 $(32 \mu \mathrm{M})$.

As observed with soil solution $\left[\mathrm{NO}_{3}\right]$, the $\left[\mathrm{NO}_{3}\right]$ in the $0.005 \mathrm{M} \mathrm{KCl}$ extract was well correlated with the EC of the soil solution $\left(r^{2}=0.81\right)$, but not for the Merredin soils alone $\left(r^{2}=0 \cdot 36\right)$. The concentrations of other ions in the $\mathrm{KCl}$ extracts were not correlated with the EC of the soil solution (data not shown).

Almost $90 \%$ of the total $\mathrm{Al}$ extracted by $\mathrm{KCl}$ was present as $\mathrm{Al}^{3+}$ and between $2 \%$ and $4 \%$ was $\mathrm{AlSO}_{4}^{+}$. There was no difference in the estimated proportions of $\mathrm{Al}$ species present in the $\mathrm{KCl}$ extracts in soils from the Merredin region compared with all other regions (Table 3 ).

Table 5. Exchangeable cations $\left(\mathrm{cmol}^{+}\right) \mathrm{kg}^{-1}$ ) of unlimed soils extracted by $1: 10 \quad 0 \cdot 1 \mathrm{M}$ $\mathrm{BaCl}_{2}$

\begin{tabular}{rccccccc}
\hline Soil & $\mathrm{Al}$ & $\mathrm{Ca}$ & $\mathrm{Mg}$ & $\mathrm{Na}$ & $\mathrm{K}$ & ECEC $^{\mathrm{A}}$ & \% Al sat. \\
\hline 1 & 0.524 & 0.447 & 0.159 & 0.029 & 0.049 & 1.208 & 43 \\
2 & 1.061 & 0.103 & 0.027 & 0.005 & 0.066 & 1.263 & 84 \\
3 & 0.497 & 0.639 & 0.171 & 0.048 & 0.075 & 1.430 & 35 \\
4 & 0.695 & 0.443 & 0.180 & 0.005 & 0.066 & 1.390 & 50 \\
5 & 0.824 & 0.531 & 0.164 & 0.019 & 0.062 & 1.601 & 51 \\
6 & 0.634 & 0.347 & 0.074 & 0.010 & 0.064 & 1.130 & 56 \\
7 & 0.840 & 0.221 & 0.042 & 0.006 & 0.051 & 1.160 & 72 \\
8 & 0.413 & 0.691 & 0.208 & 0.058 & 0.097 & 1.468 & 28 \\
9 & 0.650 & 1.285 & 0.088 & 0.061 & 0.067 & 2.151 & 30 \\
10 & 0.770 & 0.149 & 0.031 & 0.006 & 0.052 & 1.010 & 76 \\
\hline
\end{tabular}

${ }^{A}$ ECEC, effective cation exchange capacity $(\Sigma \mathrm{Al}+\mathrm{Ca}+\mathrm{Mg}+\mathrm{Na}+\mathrm{K})$. 


\section{Exchangeable cations and ECEC}

There was a considerable range in the concentration of exchangeable cations (Table 5), but no differences in concentration between the soils from the Merredin region compared with the other regions. Exchangeable $\mathrm{Al}$ varied from 0.4 to $1.1 \mathrm{cmol}(+) \mathrm{kg}^{-1}$ and occupied $28-84 \%$ of the exchange sites. Calcium was the other major exchangeable cation and varied in concentration from 0.1 to $1 \cdot 3 \mathrm{cmol}(+) \mathrm{kg}^{-1}$. Exchangeable $\mathrm{Ca}$ and $\mathrm{Na}$ were well correlated $\left(r^{2}=0 \cdot 79\right.$ and 0.89 respectively) with the concentration of the equivalent cation in the soil solution, but $\mathrm{Al}, \mathrm{Mg}$ and $\mathrm{K}$ were not well correlated $\left(r^{2}<0.31\right)$. For the Merredin soils, exchangeable $\mathrm{Na}$ and $\mathrm{Al}$ were also well correlated to the equivalent soil solution concentration $\left(r^{2}=0.99\right.$ and 0.73 respectively), while the other cations were not well correlated $\left(r^{2}<0.31\right)$.

Exchangeable $\mathrm{Mg}, \mathrm{Na}$ and $\mathrm{Al}$ in soils from all regions were well correlated $\left(r^{2}=0.94,0.86\right.$ and 0.72 respectively) to the concentration of the equivalent cation in $0.005 \mathrm{M} \mathrm{KCl}$ extracts, whereas exchangeable $\mathrm{Ca}$ was not well correlated $\left(r^{2}=0 \cdot 34\right)$. There were similar correlations in the Merredin soils $\left(r^{2}=0.89\right.$, 0.73 and 0.78 respectively), except exchangeable $\mathrm{Ca}$ was also well correlated for these soils $\left(r^{2}=0.88\right)$.

Table 6. The growth of wheat in limed and unlimed acidic soils 10 days after sowing

\begin{tabular}{|c|c|c|c|c|c|c|c|c|c|}
\hline \multirow[t]{2}{*}{ Soil } & \multicolumn{3}{|c|}{$\begin{array}{c}\text { Shoot fresh weight } \\
\left(\mathrm{g} \mathrm{pot}^{-1}\right)\end{array}$} & \multicolumn{3}{|c|}{$\begin{array}{c}\text { Root fresh weight } \\
\left(\mathrm{g} \mathrm{pot}^{-1}\right)\end{array}$} & \multicolumn{3}{|c|}{$\begin{array}{l}\text { Root length } \\
\left(\mathrm{m} \operatorname{pot}^{-1}\right)\end{array}$} \\
\hline & -Lime & +Lime & $R Y^{A}$ & -Lime & +Lime & RY & -Lime & +Lime & RY \\
\hline 1 & 0.839 & $1 \cdot 293$ & 65 & $2 \cdot 893$ & $2 \cdot 985$ & 97 & $9 \cdot 3$ & $21 \cdot 1$ & 44 \\
\hline 2 & 0.850 & $1 \cdot 656$ & 51 & $1 \cdot 208$ & $3 \cdot 721$ & 32 & $2 \cdot 1$ & $23 \cdot 4$ & 9 \\
\hline 3 & $1 \cdot 221$ & $1 \cdot 911$ & 64 & $2 \cdot 985$ & $4 \cdot 089$ & 73 & $12 \cdot 7$ & $25 \cdot 9$ & 49 \\
\hline 4 & $1 \cdot 297$ & $1 \cdot 627$ & 80 & $3 \cdot 974$ & $4 \cdot 111$ & 97 & $19 \cdot 7$ & $29 \cdot 1$ & 68 \\
\hline 5 & 0.928 & $1 \cdot 623$ & 57 & $2 \cdot 346$ & $3 \cdot 869$ & 61 & $7 \cdot 2$ & $27 \cdot 0$ & 27 \\
\hline 6 & 0.841 & $1 \cdot 205$ & 70 & $1 \cdot 775$ & $2 \cdot 881$ & 62 & $4 \cdot 0$ & $17 \cdot 0$ & 23 \\
\hline 7 & $0 \cdot 781$ & 1.093 & 71 & $1 \cdot 282$ & $3 \cdot 190$ & 40 & $2 \cdot 4$ & $22 \cdot 5$ & 11 \\
\hline 8 & $1 \cdot 420$ & 1.457 & 97 & $3 \cdot 997$ & $3 \cdot 560$ & 112 & $23 \cdot 3$ & $25 \cdot 8$ & 91 \\
\hline 9 & 1.078 & $1 \cdot 452$ & 74 & $1 \cdot 965$ & $2 \cdot 420$ & 81 & $5 \cdot 0$ & $13 \cdot 3$ & 38 \\
\hline 10 & $0 \cdot 823$ & $1 \cdot 100$ & 75 & $1 \cdot 327$ & $2 \cdot 319$ & 57 & $2 \cdot 5$ & $14 \cdot 5$ & 17 \\
\hline
\end{tabular}

A Relative yield.

\section{Plant Growth}

\section{Shoots}

In the unlimed soils, shoot fresh weight (SFW) varied from 0.82 to $1.42 \mathrm{~g} /$ pot (Table 6). There were no visual symptoms of nutrient deficiencies when the plants were harvested (Zadoks scale 11-12; Zadoks et al. 1974). The addition of lime increased SFW by $3-95 \%$. The average response to lime in SFW of plants grown in the Merredin soils was $61 \%$, whereas the average for soils from the other regions was $31 \%$.

\section{Roots}

The roots of plants growing in soils with high soil solution- and $\mathrm{KCl}$ extractable[Al] ( $>23 \mu \mathrm{M} \mathrm{Al}$ in both soil solution and $\mathrm{KCl}$ extracts) had substantially thicker 
roots, i.e. considerably less fine lateral development than those growing in soils with lower aluminium concentrations. This was reflected by root fineness (data not shown). In the unlimed soils, root fresh weights varied from 1.21 to $4.00 \mathrm{~g} / \mathrm{pot}$ and the length of these roots was between $2 \cdot 1$ and $23.3 \mathrm{~m} /$ pot (Table 6). The liming of soil substantially increased both root weight and length (Table 6). Unlike SFW, there was no difference in the response in either root weight or length after soils were limed from the Merredin region compared with the same in soils from the other regions.
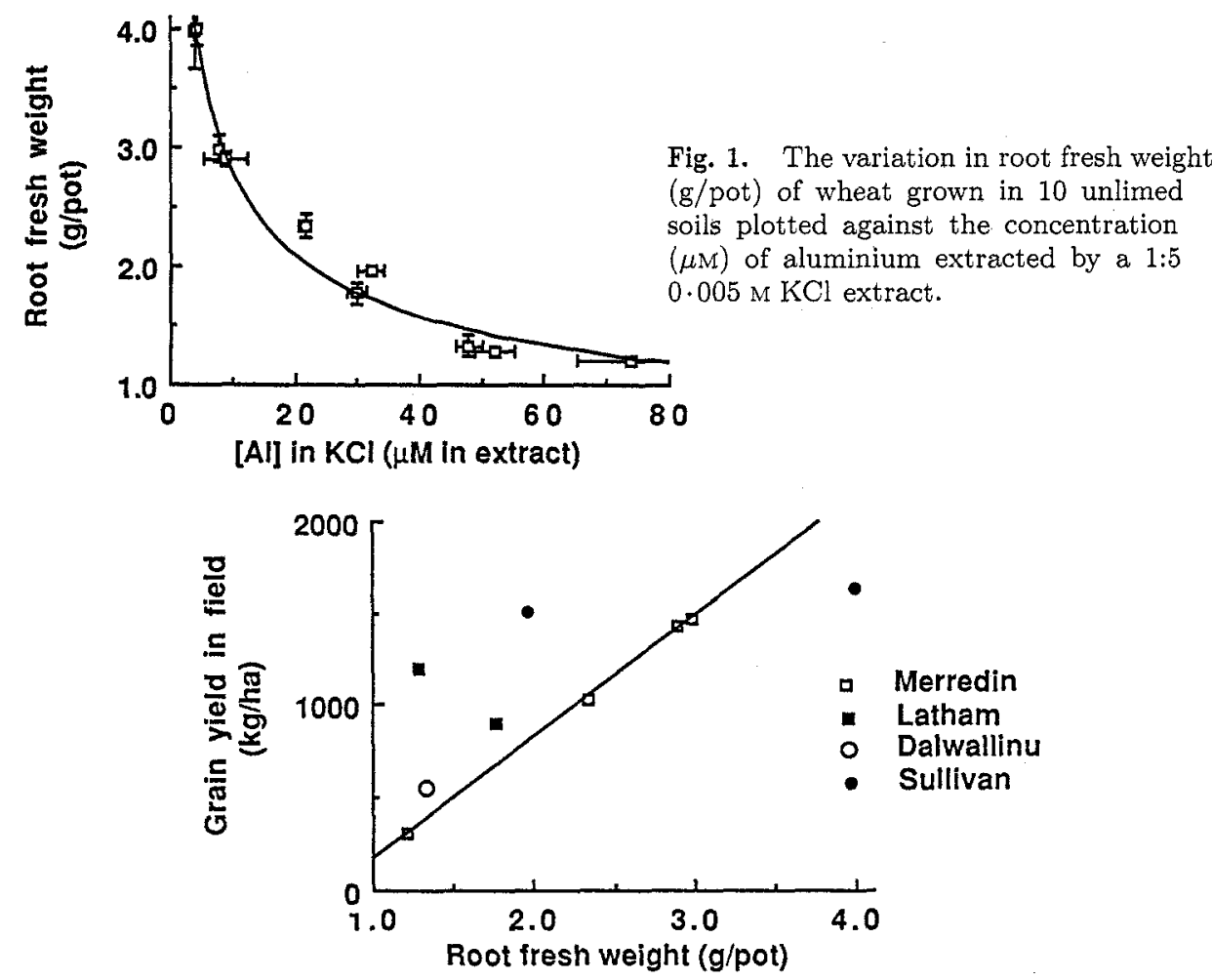

Fig. 2. The variation in grain yield $(\mathrm{kg} / \mathrm{ha})$ from field experiments plotted against root fresh weight of wheat grown in 10 unlimed soils in a glasshouse study ( $\mathrm{g} / \mathrm{pot}$ ). Line fitted through Merredin data only $\left(r^{2}=0.99\right)$.

The concentration of $\mathrm{Al}$ in a $1: 50.005 \mathrm{M} \mathrm{KCl}$ extract was able to explain $97 \%$ of the variation in root fresh weight (Fig. 1). The fresh weight of roots from plants grown in the soils from the Merredin region was also highly correlated $\left(r^{2}=0.99\right.$, Fig. 2) to the grain yield of wheat grown in the field on the site from which soil was collected for this glasshouse study. (Soil 4 was collected from a site in the Merredin region that did not have a field experiment in the previous year, hence the four data points for the Merredin region on Fig. 2.)

When soils from the other regions were included, the variation in grain yield explained by root fresh weight in the glasshouse was still reasonably high $\left(r^{2}=0.63\right.$ ), however, at two sites (soils 7 and 9) the grain yield obtained was far greater than would have been predicted on the basis of a linear correlation. This 
suggests that more data points would be needed to confirm whether a relationship exists for soils from all regions and whether it is curvilinear or linear in nature.

\section{Correlation between Soil Chemical Properties and Shoot Growth}

\section{Soil solution}

Variation in shoot fresh weight (SFW) was not adequately described $\left(r^{2}<0.54\right.$; Table 7 ) by any of the soil test indices calculated from soil solution cation and anion concentrations. There was an improvement (23-32\%) in the variation in SFW explained by [Al] when soils from Merredin were considered alone. However, this was the only index to do this. Indices that included $\mathrm{EC}$ or the ions [Ca], $[\mathrm{Na}]$ and $\left[\mathrm{NO}_{3}\right]$ were able to explain more of the variation in SFW than [Al] alone for wheat grown in all soils, but not for wheat grown in the Merredin

Table 7. Percentage variation $\left(r^{2}\right)$ in shoot and root fresh weight explained by soil test indices estimated from cation and anion concentrations in soil solution and $\mathrm{KCl}$ extracts

Equation of fitted line: $y=a x^{b}$

\begin{tabular}{ccccc}
\hline Index $^{\mathrm{A}}$ & \multicolumn{2}{c}{ Shoot fresh weight } & \multicolumn{2}{c}{ Root fresh weight } \\
& All regions & Merredin & All regions & Merredin \\
\hline & & Soil solution & \\
{$[\mathrm{Al}]$} & 23 & 32 & 58 & 96 \\
{$[\mathrm{Al}] /[\mathrm{Ca}]$} & 49 & 35 & 80 & 83 \\
{$[\mathrm{Al}] /[\mathrm{Na}]$} & 39 & 19 & 74 & 76 \\
{$[\mathrm{AI}] / \mathrm{EC}$} & 54 & 32 & 84 & 82 \\
{$[\mathrm{Al}] /\left[\mathrm{NO} \mathrm{O}_{3}\right]$} & 54 & 41 & 65 & 51 \\
$(\mathrm{Al})$ & 34 & 34 & 70 & 94 \\
$(\mathrm{AI}) /(\mathrm{Ca})$ & 53 & 28 & 84 & 82 \\
$(\mathrm{Al}) /(\mathrm{Na})$ & 53 & 28 & & \\
& & & & \\
{$[\mathrm{Al}]$} & 65 & $5 \mathrm{Cl}$ & 97 & \\
{$[\mathrm{Al}] /[\mathrm{Ca}]$} & 62 & 53 & 97 & 97 \\
{$[\mathrm{Al}] /[\mathrm{Na}]$} & 73 & 54 & 97 & 99 \\
{$[\mathrm{Al}] /\left[\mathrm{NO}{ }_{3}\right]$} & 88 & 96 & 59 & 43 \\
\hline
\end{tabular}

A Square brackets denote concentration; round brackets denote activity.

Table 8. Percentage variation $\left(r^{2}\right)$ in shoot and root fresh weight explained by Al species in soil solution

Equation of fitted line: $y=a x^{b}$

\begin{tabular}{cccccc}
\hline Species $^{\mathrm{A}}$ & \multicolumn{2}{c}{ Shoot fresh weight } & \multicolumn{2}{c}{ Root fresh weight } \\
& All regions & Merredin & All regions & Merredin \\
\hline$[\mathrm{Al}]$ & 23 & 32 & 58 & 96 \\
{$\left[\mathrm{Al}\left(\mathrm{OH}_{2}\right)^{+}\right]$} & 29 & 33 & 70 & 93 \\
{$\left[\mathrm{Al}(\mathrm{OH})^{2+}\right.$} & 35 & 25 & 70 & 72 \\
{$\left[\mathrm{Al}\left(\mathrm{SO}_{4}\right)^{+}\right]$} & 33 & 22 & 70 & 85 \\
{$\left[\mathrm{Al}^{3+}\right]$} & 21 & 34 & 54 & 98 \\
$(\mathrm{Al})$ & 34 & 34 & 70 & 94 \\
$\left(\mathrm{Al}^{3+}\right)$ & 32 & 36 & 67 & 97 \\
\hline
\end{tabular}

A Square brackets denote concentration; round brackets denote activity. 
soils alone. For example, compensation for ionic strength differences by including $\mathrm{EC}$ and/or [Ca] in the index increased the explained variation from $23 \%$ to $54 \%$ and $49 \%$ respectively. Use of the activity of aluminium, (Al), or the free ion, $\left(\mathrm{Al}^{3+}\right)$, (i.e. allowing for complexing of $\mathrm{Al}$ with $\mathrm{SO}_{4}$ ) also increased the explained variation from $23 \%$ to $32-34 \%$ (Table 8 ), but this was still inadequate.

\section{$\mathrm{KCl}$ extracts}

Soil test indices calculated from cation and anion concentrations in $\mathrm{KCl}$ extracts were better correlated with SFW $\left(r^{2}>0.62\right)$ than those calculated from soil solution concentrations (Table 7 ). The index $[\mathrm{Al}] /\left[\mathrm{NO}_{3}\right]$ in the $\mathrm{KCl}$ extract was able to explain $88 \%$ of the variation in SFW of wheat grown in soils from all regions. The variation explained by this index was increased to $96 \%$ when only soils from the Merredin region were considered. However, this was the only index estimated from $\mathrm{KCl}$ extract data that was better at describing the variation in SFW of plants grown in the Merredin soils than SFW of plants grown in soils from all regions (Table 7 ).

\section{Correlation between Soil Chemical Properties and Root Growth}

\section{Soil solution}

Root length was similar to RFW in terms of differentiating between soils with differing chemical properties (data not shown).

Variation in the RFW of wheat grown in soils from all regions was adequately described by soil test indices calculated from soil solution cation and anion concentrations $\left(r^{2}>0.58\right.$, Table 7$)$. Indices that considered $\mathrm{EC}$ or ion concentrations ( $\mathrm{Ca}, \mathrm{Na}, \mathrm{NO}_{3}$ ) in addition to [Al] were able to account for more of the variation in $\mathrm{RFW}$ than $[\mathrm{Al}]$ alone. For example, the ratio [Al] $/[\mathrm{Ca}]$ accounted for $80 \%$ and $[\mathrm{Al}] / \mathrm{EC}$ accounted for $84 \%$ of the variation in RFW which was $22 \%$ and $26 \%$ more than [Al] alone (respectively). The activity of aluminium, (Al), explained $12 \%$ more variation (i.e. $70 \%$ ) in RFW than [Al] (Table 7). When soils from the Merredin region were considered alone, most indices evaluated were able to account for an equivalent or more variation in RFW compared with the variation accounted for when all regions were considered.

Four of the five Merredin soils had $>83 \%$ of the total solution aluminium present as $\mathrm{Al}^{3+}$. Consequently there was no improvement in the variation explained in either SFW or RFW by the other minor Al species present in the soil solution (Table 8).

\section{$\mathrm{KCl}$ extracts}

Root fresh weight was highly correlated with $\mathrm{KCl}-[\mathrm{Al}]$, explaining $97 \%$ of the variation in RFW of wheat grown in these soils. There was no improvement in explained variation when the concentrations of other ions $\left(\mathrm{Ca}, \mathrm{Na}, \mathrm{NO}_{3}\right)$ were considered. In fact, there was a substantial decrease $(97-59 \%)$ in the variation explained by the ratio $[\mathrm{Al}] /\left[\mathrm{NO}_{3}\right]$. The soil tests evaluated did not explain more variation in the RFW of plants grown in the Merredin soils compared with those grown in soils from all regions (Table 7 ).

The use of relative yield rather than absolute yield did not increase the correlation between yield (either SFW or RFW) and any of the soil tests investigated (data not shown). 


\section{Discussion}

The chemical properties of the soil solution of the Merredin and other soils were found to be different. Ionic strength appeared to be the major difference and possibly the formation of $\mathrm{Al}\left(\mathrm{SO}_{4}\right)^{+}$. Both these factors alter the proportion of total [Al] in the soil solution which is toxic to plants. Short term root growth of wheat in the glasshouse was highly correlated with some soil test indices, and with grain yield in the field, whereas shoot growth was not highly correlated. The total [Al] in the soil solution was unable to adequately explain root growth in soils from different regions, but total $\mathrm{Al}$ extracted by 1:5 $0.005 \mathrm{M} \mathrm{KCl}$ could explain root yield. Presumably the $\mathrm{KCl}$ extraction was able to simulate the effect of ionic strength and speciation on toxic Al. This is supported by the fact that indices, which included EC or ion concentrations correlated to the EC of the soil solution, were better able to explain plant growth in soils from all regions, whereas the same indices estimated from the $\mathrm{KCl}$ extracts offered no improvement over $\mathrm{KCl}-[\mathrm{Al}]$ alone.

This research has provided evidence that there are inherent soil chemical differences on the yellow earth sandplain soils in the eastern wheatbelt of Western Australia. The total [Al] in the soil solution from the $15-25 \mathrm{~cm}$ depth of soils in the Merredin region has previously been shown to be correlated to grain yield of wheat in the field (Carr et al. 1991). In the controlled environment, glasshouse study reported here, total [Al] in the soil solution was highly correlated to root growth of wheat in soils from that region. This suggests that soils in the Merredin region may have a uniform parent material, and farmers in that region have used similar management practices. The difference in soil chemical properties between soils in the Merredin and other regions is more likely to be due to differences in parent material because management practices are similar in most regions of the eastern wheatbelt.

When the chemical differences in the soil solution are considered in relation to plant growth, ionic strength appeared to play an important role in controlling toxic Al. For example, root fresh weight (RFW) in soil 9 was much greater than RFW in soil 2, even though the total [Al] and $\left[\mathrm{Al}^{3+}\right]$ were similar in both soils. However, the ionic strength of the soil solution was higher in soil 9 and hence the activity of $\mathrm{Al}^{3+}(67 \mu \mathrm{M})$ was considerably less than in soil $2(109 \mu \mathrm{M})$. The extent of formation of the non-toxic ion pair $\mathrm{Al}\left(\mathrm{SO}_{4}\right)^{+}$(Cameron et al. 1986) could be another difference in the chemical properties of soils from different regions which affects the toxicity of Al. Soils collected from the Merredin region all had a smaller proportion of total [Al] present as $\mathrm{Al}\left(\mathrm{SO}_{4}\right)^{+}$. The higher concentration of $\mathrm{Al}\left(\mathrm{SO}_{4}\right)^{+}$at site 7 may have contributed to the grain yield at that site, which was greater than predicted by considering total [Al].

Several factors are thought to mitigate aluminium toxicity (Ritchie 1989; Taylor 1991). One hypothesis has been that an increase in the ionic strength decreases the activity of toxic Al (Adams and Lund 1966). Our data support this suggestion because the index $[\mathrm{Al}] / \mathrm{EC}$ was able to explain $30 \%$ more of the variation in SFW of plants grown in soils from all regions than soil solution [A]] alone. Although allowance for ionic strength differences (by including EC in the soil test index) improved the ability of soil tests to describe variation in SFW, the overall ability of these indices was still poor $\left(r^{2}<0.54\right)$.

Variation in RFW of wheat grown in the Merredin soils was best explained by [Al] alone. Because chemical differences between regions affected plant response 
to aluminium, explanation of RFW of wheat grown in soils from other regions had to be divided by the EC of the soil solution (or the concentration of certain ions in the soil solution) before being able to adequately explain variation.

The $[\mathrm{Al}]$ in the $\mathrm{KCl}$ extract was able to explain root growth in all regions because the $\mathrm{KCl}$ extraction simulated the effect of ionic strength on toxic $\mathrm{Al}$ in the soil solution. Soils with a low ionic strength will have a higher proportion of $\mathrm{Al}^{3+}$ in solution (i.e. a toxic form) than soils with a higher ionic strength. Addition of $0.005 \mathrm{M} \mathrm{KCl}$ to a soil with a low ionic strength is likely to displace more Al from soil surfaces than when $\mathrm{KCl}$ is added to a soil with a higher ionic strength. This may indicate that the variation in yields observed in the field by Carr et al. (1991) was possibly due to regional differences and management practices because the $\mathrm{KCl}$ extraction had effectively simulated the effects of chemical differences on $\mathrm{Al}$ toxicity.

Root fresh weight of wheat after 10 days growth in acidic subsoils appeared to be a promising bioassay for predicting grain yields in the field. This is because grain yields of wheat grown on yellow earths in the eastern wheatbelt of Western Australia are dependent upon adequate subsoil root proliferation to utilize subsoil water when the topsoil dries out towards the end of the growing season. For the Merredin soils, grain yield of wheat in the field would be unlikely to exceed $800 \mathrm{~kg} \mathrm{ha}^{-1}$ if root fresh weight in the glasshouse was less than $2 \mathrm{~g} \mathrm{pot}^{-1}$. Yields less than $800 \mathrm{~kg} \mathrm{ha}^{-1}$ are not economically viable.

The low correlations of shoot growth with soil test indices and Al species were partly due to the short growth period (10 days) and partly due to an unequal distribution of points along the $x$ axis (the horizontal portion of the curve at high $x$ values was only defined by one data point). In addition, the data for soil 9 appeared as an outlier with a much higher yield than predicted by the curve that could be fitted through the rest of the points, irrespective of the choice of soil test index. The anomolously high shoot growth could have been due to a soluble nitrate concentration in soil 9 that was approximately $4-8$ times higher than the soluble nitrate concentrations in the other soils. Despite the short growth period in the glasshouse experiment, the majority of the variation in SFW was explained by the ratio $[\mathrm{Al}] /\left[\mathrm{NO}_{3}\right]$ in the $\mathrm{KCl}$ extract. This may indicate far more reliance on available soil nitrogen for early growth (shoot and root) of young wheat seedlings than previously considered.

The concentrations of cations extracted in $0.1 \mathrm{M} \mathrm{BaCl}_{2}$ were not correlated to either SFW or RFW. Presumably, the high ionic strength of the $\mathrm{BaCl}_{2}$ did not extract ions in proportion to their effect on aluminium toxicity (Whitten and Ritchie 1991).

The application of lime to these acidic subsoils resulted in predictable increases in plant growth, particularly root length (data not shown). In general, yield increases after liming are attributed to alleviation of Al toxicity (Adams 1981; Gonzalez-Erico et al. 1979), and the presence of more readily plant-available Ca (Hourigan et al. 1961). In this experiment, alleviation of Al toxicity is most likely to have resulted in the yield increase.

\section{Conclusions}

The ability of $\mathrm{KCl}$ extractable aluminium to explain variation in shoot and root fresh weights indicated that the relative proportion of Al extracted was 
closely correlated with the toxic fraction of $\mathrm{Al}$ present in the soils evaluated. In a controlled glasshouse environment, a considerable proportion of the variation in short-term plant growth can be explained by appropriate soil tests. In the field environment, where other factors such as moisture supply and temperature are considerably more variable, it is logical to expect the ability of soil tests to explain variation in plant growth to be restricted. Nevertheless, the use of this $\mathrm{KCl}-[\mathrm{Al}]$ as a soil test appears very promising.

This study also indicated that the most suitable yield measurement for use in a bioassay to distinguish between soils with Al toxicity problems would be short term root fresh weight. Root fresh weight is easily determined and it is well correlated to $\mathrm{KCl}-[\mathrm{Al}]$. More comprehensive application of this bioassay technique could be a useful step in extending the soil tests developed to a wider range of soils in other regions.

\section{Acknowledgments}

We would like to thank Dr C. McLay for commenting on an earlier draft of this paper and the Wheat Research Committee of Western Australia for funding the research.

\section{References}

Adams, F. (1981). Alleviating chemical toxicites: Liming acid soils. In 'Modifying the Root Environment to Reduce Crop Stress'. (Eds G. F. Arkin and H. M. Taylor.) ASAE Monograph No. 4. pp. 267-301. (American Society of Agric. Engineers: St. Joseph Mich.)

Adams, F., and Lund, Z. F. (1966). Effect of chemical activity of soil solution aluminium on cotton root penetration of acid subsoils. Soil Science 101, 193-8.

Adams, F., and Moore, B. L. (1983). Chemical factors affecting root growth in subsoil horizons of coastal plain soils. Soil Sci. Soc. Am. J. 47, 99-102.

Bettenay, E., and Hingston, F. J. (1961). The soils and land use of the Merredin area, Western Australia. CSIRO Aust. Div. Soils, Soils Land Use Ser. No. 41.

Cabaniss, S. E. (1987). TITRATOR: An interactive program for aquatic equilibrium calculations. Environ. Sci. Technol. 21, 209-10.

Cameron, R. S., Ritchie, G. S. P., and Robson, A. D. (1986). Relative toxicities of inorganic aluminium complexes to barley. Soil Sci. Soc. Am. J. 50, 1231-6.

Carr, S. J., Ritchie, G. S. P., and Porter, W. M. (1991). A soil test for subsoil aluminium toxicity in the yellow earth soils of Western Australia. Aust. J. Agric. Res. 42, 875-92.

Foy, C. D. (1974). Effects of aluminium on plant growth. In "The Plant Root and Its Environment'.(Ed. E. W. Carson.) (Univ. Press of Virginia: Charlottesville, Va.)

Gillman, G. P. (1976). A centrifuge method for obtaining soil solution CSIRO Aust. Div. Soils, Div. Report No. 16.

Gonzalez-Erico, E., Kamprath, E. J., Naderman, G. C., and Soares, W. V. (1979). Effect of depth of lime incorporation on the growth of corn on an Oxisol of Central Brazil. Soil Sci. Soc. Am. J. 43, 1155-8.

Hourigan, W. R., Franklin, Jr, R. E., McLean, E. O., and Bhumbla, D. R. (1961). Growth and Ca uptake by plants as affected by rate and depth of liming. Soil Sci. Soc. Am. Proc. $43,491-4$.

Lindsay, W. L. (1978). Chemical equilibria in soils. (John Wiley: New York.)

Martell, A. E., and Smith, R. M. (1977). 'Critical Stability Constants: Other Organic Ligands. Vol. 3.' (Plenum Press: New York.)

Pinkerton, A., and Simpson, J. R. (1981). Effects of subsoil acidity on the shoot and root growth of some tropical and temperate forage legumes. Aust. J. Agric. Res. 32, 453-63.

Porter, W. M., and Wilson, I. (1984). Soil acidity in the eastern wheatbelt. J. Agric. West. Aust. 25, 132-5. 
Radcliffe, D. E., Clark, R. L., and Sumner, M. E. (1986). Effect of gypsum and deep rooting perennials on subsoil mechanical impedance. Soil Sci. Soc. Am. J. 50, 1566-70.

Ritchie, G. S. P. (1989). The chemical behaviour of aluminium, hydrogen and manganese in acid soils. In 'Soil Acidity and Plant Growth'. (Ed. A. D. Robson.) pp. 1-60. (Academic Press: Sydney.)

Taylor, G. J. (1991). Current views of aluminium stress response; The physiological basis of tolerance. Curr. Topics Plant Biochem. Phys. 10, 57-93.

Whitten, M. G., and Ritchie, G. S. P. (1991). A comparison of soil tests to predict growth and nodulation of subterranean clover in acidic topsoils. Plant Soil 136, 11-24.

Zadoks, J. C., Chang, T. T., and Konzal, C. F., (1974). A decimal code for the growth stage of cereals. Weed Res. 14, 415-21. 